\title{
Pelatihan Membuat Lamak Tamiang dan Tata Rias Mesanggul Bali
}

\author{
Ni Kadek Karuni*1, I Wayan Suardana², Ni Putu Darmara Pradnya Paramita, \\ Ni Luh Ayu Pradnyani Utami ${ }^{4}$ \\ 1,2,3,4 Institut Seni Indonesia Denpasar \\ *email: kadekkaruni8@gmail.com¹, Suar.tulu63@gmail.com²,putumita.dpp@gmail.com³, \\ pradnyaniayu9gmail.com ${ }^{4}$
}

\begin{abstract}
The service's partner was WHDI Desa Guwang, the women group of Hindu Dharma Indonesia in Desa Guwang, Kecamatan Sukawati, Kabupaten Gianyar Bali. The purpose of this service program was to overcome major problems found in WHDI Desa Guwang in Kecamatan Sukawati Kabupaten Gianyar in which the members of WHDI Desa Guwang have not had any skills to create ceremonial tools such as Lamak and Tamiang for ceremonial needs; in addition, most of them have not been able to do makeup and hairstyling independently, especially for ceremonial activities or others. The first program was skill training for creating Lamak and Tamiang for groups of WHDI Desa Guwang which was purposed to make the members as well as the management of WHDI able to have skill on creating Lamak and Tamiang independently. These training was done on a schedule by inviting speakers or experts who possess competency on related field. The second program was giving a training to do makeup and hairstyling (Balinese bun) for going to the temple and Balinese ceremony. The methods of the study included communicative talks, training, accompaniment, and evaluation. In order to find solutions for these problems, the study involved lecturers of Faculty of Fine Arts in ISI Denpasar who possess competency on related field. The results of the study was to upgrade knowledge and skill of the members of WHDI Desa Guwang to create Lamak and Tamiang for ceremonial tools as well as Hindus ceremonial decoration; in addition, the members were also able to do makeup and Balinese bun independently.
\end{abstract}

Keywords: Lamak, Tamiang, Makeup, Balinese Bun

\begin{abstract}
Abstrak
Mitra dalam pengabdian ini adalah WHDI desa Guwang yaitu kelompok wanita Hindu Dharma Indonesia yang berada di desa Guwang kecamatan Sukawati Kabupaten Gianyar Bali. Tujuan dari program pengabdian ini adalah ingin menyelesaikan permasalahan prioritas yang ditemukan pada WHDI Desa Guwang di Kecamatan Sukawati Kabupaten Gianyar yaitu anggota WHDI Desa Guwang belum memiliki keterampilan membuat sarana upakara berupa Lamak dan Tamiang untuk keperluan upacara agama dan adat, serta kebanyakan belum bisa merias wajah, menata dan merias rambut secara mandiri terutama untuk acara kegiatan ke pura atau acara adat lainnya. Program pertama yang dilakukan adalah memberikan pelatihan keterampilan membuat Lamak dan Tamiang kepada kelompok WHDI Desa Guwang, agar anggota dan pengurus WHDI mampu dan terampil membuat Lamak dan Tamiang secara mandiri. Pelatihan ini dilakukan secara terjadwal dan menghadirkan nara sumber/tenaga ahli yang memiliki kompetensi baik dibidang ini. Program kedua dengan memberikan pelatihan tata rias wajah termasuk dalam tata rias rambut (mesanggul Bali) untuk ke pura dan upacara adat di Bali. Metode pelaksanaannya, ceramah, pelatihan, pendampingan dan evaluasi. Untuk memecahkan persoalan ini melibatkan dosen dari FSRD ISI Denpasar yang memiliki kompetensi di bidang ini. Hasil dari kegiatan pengabdian ini adalah meningkatnya pengetahuan dan keterampilan anggota WHDI desa Guwang dalam membuat Lamak dan Tamiang sebagai sarana upakara maupun sebagai sarana dekorasi dalam upacara adat dan agama Hindu. Anggota WHDI juga mampu merias wajah dan mesanggul secara mandiri.
\end{abstract}

Kata Kunci : Lamak, Tamiang, Tata Rias, Mesanggul Bali

\section{PENDAHULUAN}

Mitra dalam usulan pengabdian ini adalah kelompok Wanita Hindu Dharma Indonesia (WHDI) Desa Guwang di Kecamatan Sukawati Kabupaten Gianyar Bali yang berjumlah 20 orang. WHDI merupakan suatu wadah/organisasi wanita yang bergerak dalam bidang sosial kemasyarakatan dan keagamaan guna menampung aspirasi dan kreativitas, yaitu terwujudnya wanita Hindu yang cerdas, mandiri dan berbudi pekerti luhur dengan budaya organisasi modern. 
Meningkatkan kualitas sumber daya manusia wanita Hindu, dan mengembangkan sikap positif dalam berkarya (KOWANI, diakses 27 juni 2020). Dalam rangka menempatkan organisasi menjadi eksis di tengah masyarakat, hal yang terpenting adalah, program kegiatan organisasi yang dibuat harus merupakan representasi dari kebutuhan anggotanya. Demikian juga dengan keberadaan kelompok WHDI desa Guwang di kecamatan Sukawati. WHDI Desa Guwang yang telah berjalan selama 2 tahun telah melaksanakan program yang selalu mengacu pada visi misi dari WHDI.

Ketika kami melakukan survey kelapangan, Ketua WHDI Desa Guwang Ni Ketut Ayu Natih (51 tahun) pada 3 Januari 2020 di rumahnya menjelaskan bahwa WHDI Desa Guwang yang secara resmi didirikan tahun 2018, yang bergerak dalam bidang sosial kemasyarakatan dan keagamaan memiliki beberapa kegiatan yang telah dijalankan setiap tahun. Kegiatan tersebut misalnya pelatihan membuat banten yang didanai dari dana desa. Mengadakan kegiatan arisan dan jimpitan diantara anggota yang dilakukan setiap bulan sekali. Kegiatan metirta yatra kepura-pura di daerah Bali dan luar Bali. Kegiatan sosial lain juga sudah dilakukan yang diberi nama "anjang sana" adalah kegiatan berbagi dengan keluarga kurang mampu yaitu dengan pemberian sembako kepada keluarga miskin di Desa Guwang. Ketua WHDI Desa Guwang sangat berkeinginan wanita Hindu yang ada di Desa Guwang tidak keluar dari Hindu, maka dari itu mereka harus diberi beberapa keterampilan berkaitan dengan budaya Bali, sehingga mereka lebih sibuk dan lebih menyukai budayanya. Sebagai mitra Ketua WHDI Desa Guwang juga mengatakan permasalahan yang dihadapi saat ini adalah keterampilan yang dimiliki anggotanya masih perlu untuk ditingkatkan berkaitan dengan budaya Bali, misalnya keterampilan dalam membuat Lamak dan Tamiang.

Selama ini jika ada upacara adat dan agama, benda-benda seperti Lamak dan Tamiang tersebut didapatkan dengan cara membeli, bukan dengan cara membuat sendiri. Walaupun sebetulnya hal ini tidak masalah karena cukup mudah di dapatkan dan murah, tetapi sebagai wanita Hindu sebaiknya harus memiliki keterampilan dalam membuatnya sebagai jati diri wanita Hindu yang ada di Bali yang kental dengan seni budayanya, agar kedepan dapat diteruskan pada generasi berikutnya, sehingga wacana ajeg Bali dapat diimplementasikan nyata melalui kegiatankegiatan yang kecil seperti ini. Masyarakat Bali (Hindu) mengenal banyak sarana dan prasarana upakara, di mana salah satunya dinamai Lamak. Jejahitan Lamak adalah salah satu jejahitan yang bahan dasarnya dibuat dari daun enau, (pohon sagu ) yang muda (ambu) dan daun enau tua (ron). Bentuk dasar jejahitan Lamak ini segi empat panjang dengan lebar kurang lebih $35 \mathrm{~cm}$ kali 2 atau 3 meter bahkan lebih sesuai dengan kebutuhan pada tempat upacara. Jejahitan Lamak merupakan gambaran alam semesta ini di mana didalamnya terdapat bulan, bintang, matahari, tumbuh tumbuhan dan sebagainya (Raka, 1977/1978, 21). Lamak berarti dasar atau tempat duduk Tuhan/ Ida Sang Hyang Widhi Wasa. Maksudnya di dalam upacara agama Hindu di Bali Lamak dilukis sebagai dasar atau alas tempat duduk Tuhan/ Ida Sang Hyang Widhi Wasa saat dilangsungkan upacara. Karena dalam pengertian Hindu beliau adalah sang pencipta alam semesta ini dan bertakhta diatas alam semesta ini, maka pada saat upacara dibuatkan gambaran alam semesta yang berwujud Lamak sebagai alat tempat duduk beliau. (Merta Dewa, Karuni, 2003:86). Budayawan Kota Denpasar, Gede Anom Ranuara menjelaskan bahwa Lamak merupakan salah satu perlengkapan atau uperengga upakara di Bali yang termasuk dalam gologan Cenigan. "Cenigan merupakan kelengkapan upakara yang terbuat dari dedaunan dan diletakkan di beberapa lokasi, di antaranya di palinggih dan pelangkiran. (Ranuara, baliexpress.jawapos , diakses 27 Juni 2020).

Lamak biasanya ditempatkan di palinggih maupun Sanggah Surya, ketika ada upacara Panca Yadnya. Menurut salah satu seniman yang ahli dalam hal majejaitan, I Wayan Sumatra, 65, Lamak yang baik dan benar adalah Lamak yang mengandung simbol dari tiga alam atau Tri Bhuana.Tri Bhuana itu terdiri dari alam Bhur (bawah) seperti tanah atau pertiwi. Kemudian Bwah (tengah), yang terdiri dari Eka Pramana (tumbuhan), Dwi Pramana (binatang), dan Tri Pramana (manusia atau Cili). Dan, Swah (atas) ada matahari, bulan, dan bintang. " Dalam Lamak, Tri Bhuana itu diaplikasikan dalam bentuk jejaitan, reringgitan. Jadi, Tri Bhuana itu wajib dihadirkan dalam Lamak(baliexpress.jawapos.com. diakses 27 juni 2020). Berdasarkan Lontar Tutur Rare 
Angon, terdapat tiga jenis Lamak di Bali. Hal ini sesuai dengan tata cara pemasangan Lamak tersebut. Tiga jenis Lamak tersebut adalah Lamak Terujungan yang biasanya dipasang di lebuh atau halaman depan rumah, ketika pelaksanaan upacara Bhuta Yadnya atau Tawur. Kedua, yakni Lamak kecil yang biasa digunakan pada beberapa palinggih, seperti Apit Lawang dan tugu. Dan yang ketiga adalah Lamak Besar yang biasa dipasang di palinggih besar, seperti Padmasana, Gedong dan lain sebagainya. Selain itu, Lamak biasanya dibuat dengan berbagai jenis ukuran. Ketika ada upacara yadnya di desa Guwang terutama di pura khayangan Tiga: pura Desa, Pura Puseh dan Pura Dalem, Jejahitan Lamak ini harus ada untuk dipajang di setiap pelinggih pelinggih.

Di beberapa desa di Bali, seperti di Desa Mas, Ubud, Kabupaten Gianyar, masyarakat Hindu saat perayaan hari suci Galungan membuat Lamak dengan ukuran panjang sekitar 2,5 meter. Hal ini tentu menjadi unik dan memiliki daya tarik tersendiri. Sementara Tamiang adalah merupakan sarana upakara yang bentuknya bulat seperti periasi, dirajut dengan indah dari bahan daun kelapa muda atau janur, dikombinasikan dengan daun enae berwarna hijau, sehingga kelihatan lebih indah. Dalam agama Hindu Tamiang menyimbolkan sebuah tameng yang menjadi perisai dalam perang. Tamiang sendiri sering dimaknai dengan simbol perlindungan diri karena bentuknya seperti perisai, bentuknya yang bulat dipahami juga sebagai lambang Dewata Nawa Sanga yang merupakan penguasa sembilan arah mata angin. Tamiang juga diartikan sebagai roda alam atau cakraning manggilingan yang dipahami sebagai roda kehidupan yang selalu berputar. Semuanya menjadi warisan budaya Hindu yang terjaga dengan baik yang berkaitan dengan kehidupan beragama di pulau Dewata Bali (balitoursclub.net, diakses 27 juni 2020). Tamiang biasanya dibuat ketika hari raya Kuningan, dipajang di bagian atas pelinggih. Seperti yag sering disaksikan dalam pelaksanaan Upacara Dewa Yadnya, Lamak dan Tamiang yang bermaterialkan Janur dan ron tersebut dianggap jenis jejaitan yang sangat rumit bagi ibu ibu yang belum terbiasa membuatanya. Tetapi bila mau dipelajari sebenarnya tidak begitu sulit. Hal inilah yang belum dipahami oleh ibu ibu WHDI desa Guwang. Oleh karena itu, maka perlu dicarikan solusinya, agar ibu-ibu WHDI menguasai teknik membuat Lamak yang baik dan benar, memahami akan makna, arti dan fungsi Lamak dan Tamiang dalam upacara yadnya di Bali yang sesuai dengan tattwa agama Hindu di Bali, sehingga wacana mengajegkan Bali dapat diimplementasikan secara nyata.

Permasalahan lain yang diungkapkan Ketua WHDI Desa Guwang adalah setiap ada piodalan di pura, upacara Dewa yadnya atau kegiatan adat lainnya di masyarakat, ibu-ibu selalu berhias ke salon untuk mempercantik diri. Sehingga menghabiskan waktu yang dirasakan cukup lama, maka akan mengganggu pekerjaan lainnya. Apalagi kalau mendapat giliran ngayah tari rejang renteng, ibu ibu pada bingung mencari salon untuk berhias dan mesanggul. Ibu-ibu kebanyakan belum bisa merias wajah dan menata rambut sendiri. Hal ini menyebabkan pada saat-saat tertentu salon-salon kecantikan terdekat dipenuhi oleh dengan antrean ibu ibu, menunggu giliran untuk berhias. Maka dari itu permasalahan ini perlu dicarikan solusinya. Kami menemukan dua permasalahan prioritas pada WHDI Desa Guwang yang perlu dicarikan solusi. Sehingga dalam usulan pengabdian ini kami mengajukan 2 permasalahan tersebut yaitu : Pertama, Pelatihan membuat Lamak dan Tamiang. Ke dua, adalah Pelatihan merias wajah dan menata rambut (Mesanggul Bali) untuk mengikuti kegiatan keagamaan. Tujuan dan manfaat dari pelatihan membuat Lamak dan Tamiang agar ibu ibu WHDI dapat menambah wawasan dan pengetahuan tentang Lamak dan Tamiang, serta menguasai keterampilan yang memadai, untuk membuat Lamak dan Tamiang, terutama dalam memahami makna, fungsi dan bentuk jejahitan Lamak serta diharapkan mampu membuat Lamak secara mandiri untuk perlengkapan sarana upacara agama, sehingga tidak membeli lagi saat ada upacara agama. Apabila telah mampu membuat sendiri, ini juga bisa dikembangkan untuk di jual ketika ada pesanan, sehingga dapat menambah ekonomi keluarga.

Demikian juga dengan pelatihan merias wajah dan menata rambut (mesanggul Bali). Dengan mendapatkan pelatihan ibu ibu diharapkan dapat menambah wawasan dan pengetahuan tentang tata rias wajah dan rambut (mesanggul Bali) pada anggota WHDI desa Guwang yang belum memiliki pengetahuan dan menguasai ketrampilan dalam merias wajah dan menata rambut untuk mengikuti kegiatan keagamaan dan adat lainnya secara mandiri, karena 
penampilan juga perlu diperhatikan dalam menghadiri setiap upacara adat dan agama di Bali. Apabila telah menguasai keterampilan merias wajah dan mesanggul sendiri secara mandiri, sehingga ibu ibu tidak perlu lagi pergi kesalon untuk berhias. Disamping itu diharapkan ketika telah mampu merias wajah dan menata rambut secara mandiri, kedepannya akan bisa merias wajah dan menata rambut orang lain, ini juga akan dapat menambah ekonomi keluarga.

\section{METODE}

Metode yang diterapkan dalam pelaksanaan pengabdian ini adalah:

\section{a. Metode observasi dan wawancara}

Metode ini dilakukan mulai dari tahap awal penyusunan proposal pengabdian ini. Kami dari tim Kami melakukan obervasi pada kelompok WHDI desa Guwang di Kecamatan Sukawati Kabupaten Gianyar .Ditengah-tengah kesibukan ibu ibu WHDI, mereka menyempatkan diri melayani kami dalam sebuah pertemuan. Dalam pertemuan tersebut kami mengadakan wawancara dan diskusi mengenai kegiatan kegiatan yang telah dilaksanakan, capaian capain program yang telah diperoleh dan permasalahan atau kendala kendala yang dihadapi ibu ibu WHDI saat ini dan pelaksanaan program kegiatan yang telah disusun kedepannya. Dalam wawancara dilakukan secara terbuka sehingga Ibu Ibu WHDI dapat mengemukaan berbagai permasalahan yang dihadapi secara bebas tanpa ada perasaan untuk menyembunyikan sesuatu. Dari hasil wawancara diperoleh informasi bahwa sebagian besar anggota WHDI desa Guwang saat ini belum memiliki keterampilan dalam membuat Lamak sebagai salah satu sarana upakara dalam upacara agama Hindu. Ibu ibu WHDI juga menghadapi kendala dalam merias wajah dan menata rambut sendiri ketika ada kegiatan upacara agama dan adat, sehingga permasalahan ini perlu dicarikan solusinya. Dari diskusi intensif tersebut kami menguraikan seluruh permasalahan yang dihadapi oleh ibu ibu WHDI, kemudian menimbang, memilah, meklasifikasikan, merunutkan, memperkirakan metode pelaksanaannya, sehingga menemukan permasalahanpermasalahan yang urgen dan memerlukan penyelesain segera yang berdampak positif pada peningkatan kemampuan dan keterampilan mitra dalam melaksanakan program kegiatan kedepannya. Dari hasil observasi dan wawancara tersebut, kami dari tim Kami merumuskan hasil wawancara seperti tertuang dalam permasalahan diatas. Setelah perumusan permasalahan dan kesiapan mitra dalam menerima solusi penyelesaian masalah yang Kami tawarkan , maka langkah selanjutnya adalah melakukan perijinan serta konsultasi pada berbagai pihak terutama kepada Kepala Desa Guwang, Bendesa adat Pekraman desa Guwang dan ketua WHDI Desa Guwang untuk berkoordinasi dengan pengurus dan anggotanya .

\section{b. Metode Ceramah, Pelatihan disertai Pendampingan.}

Metode ceramah merupakan sosialisasi mengenai solusi penyelesaian masalah masalah yang dihadapi, disertai dengan penjelasan alat, bahan, dan cara pembuatannya. Langkah-langkah yang dilakukan untuk menyelesaikan kedua aspek permasalahan dari ibu ibu WHDI adalah pertama menyelesaikan permasalahan yang berkaitan dengan aspek pembuatan salah satu sarana upakara agama Hindu berupa Lamak dan Tamiang, kemudian dilanjutkan dengan aspek kedua mengenai tata rias wajah dan rambut. Tahap ini bertujuan memberi memotivasi pada anggota WHDI desa Guwang untuk belajar, berlatih dan menambah wawasan tentang arti, fungsi, dan makna sebuah sarana upakara dalam kegiatan upacara yadnya di Bali. Metode ceramah juga diberikan untuk mensosialisasikan cara berbusana, merias dan menata rambut (mesanggul Bali) yang baik dan benar ketika mengikuti kegiatan kegiatan upacara adat dan agama. Partisipasi ibu ibu WHDI mengikuti pelaksanaan program ini cukup aktif dalam setiap tahapan, aktif bertanya, sesuai dengan arahan tenaga ahli dan pendamping yang lainnya. Pada pertemuan minggu berikutnya dilakukan dengan metode partisipasi aktif. Amalia dalam Munawarah menjelaskan metode partisipasi aktif atau disebut juga metode Participatory Action Research (PAR). Metode ini bertujuan untuk membangun kesadaran masyarakat sekaligus memberdayakan masyarakat kelas menengah ke bawah melalui pemberian penyuluhan dengan materi yang telah ditentukan 
(Munawarah et al., 2020: 436). Pelatihan dan pendampingan membuat Lamak berkaitan dengan cara metetuesan, cara menerapkan hiasan dan teknik menyusun hiasan sehingga ibu ibu WHDI mampu membuat Lamak secara mandiri. Demikian juga dengan pelatihan merias wajah, dilaksanakan pada bulan berikutnya dengan tahapan pengenalan make up, model sanggul dan cara penerapannya, sehingga ibu ibu bisa merias dan mesanggul sendiri secara berkelanjutan. Kemudian pada akhir pertemuan dilakukan evaluasi untuk mengetahui sejauh mana kegiatan ini telah berjalan dan bermanfaat bagi mintra.

\section{HASIL DAN PEMBAHASAN}

Kegiatan pengabdian masyarakat pada kelompok Wanita Hindu Dharma (WHDI) desa Guwang kecamatan Sukawati Kabupaten Gianyar walaupun dimasa pandemic covid-19 namun dapat berjalan dengan lancar dan seluruh kegiatan dapat terealisasikan dengan baik. Pelaksanaan pelatihan yang dilakukan dengan tetap menerapkan protokol Kesehatan, yaitu dengan menggunakan masker, mencuci tangan dan menjaga jarak. Disamping itu, keberhasilan pelaksanaan pelatihan ini, juga semua berkat kerjasama yang baik antara team pelaksana kegiatan, nara sumber dengan peserta pelatihan. Masyarakat dalam hal ini Ketua, pengurus dan anggota WHDI desa Guwang memberi dukungan dan respon yang baik, mereka antusias mengikuti kegiatan yang berlangsung. Kepala Desa dan Bendesa adat desa pekraman Guwang juga menyambut baik kegiatan ini bahkan mendukung untuk pelaksanaan pelatihan berikutnya. Program pertama yang dilakukan dalam pelaksanakan pengabdian ini adalah pelatihan membuat salah satu sarana upakara agama Hindu berupa Lamak dan Tamiang. Kegiatan diawali dengan metode ceramah, memberikan pemahaman tentang jejahitan Lamak dan Tamiang, berkaitan dengan makna, fungsi dan bentuk Lamak dalam setiap upacara agama Hindu di Bali. Melihat dari fungsinya jejahitan Lamak memiliki fungsi yang ganda. Lamak berfungsi sebagai simbol alas atau dasar tempat duduk Ida Sang Hyang Widhi Wasa. Karena jejahitan Lamak ini dibuat penuh dengan makna yang diwujudkan berupa simbol-simbol kehidupan yang ada di alam semesta yang melambangkan kehidupan di tiga alam disebut Tri Loka yaitu alam bawah (Bhur Loka), alam Tengah (Bwah Loka), Alam atas (Swah Loka). Lamak sebagai symbol alam semesta merupakan tempat bertakhta dan tempat duduk Ida Sang Hyang Widhi Wasa dalam upacara agama hindu.

Disamping fungsi Lamak sebagai symbol alam semesta, Lamak juga dipakai sebagai dekorasi atau hiasan dipasang pada pintu-pintu pelinggih , karena Lamak mengandung unsur keindahan yang terlihat dari bentuk dan reringgitannya. Saat itu para umat mempersembahkan yang terbaik, hal ini dilakukan dengan membuat simbol-simbol beliau lewat karya seni. Dalam pertemuan ini ibu ibu WHDI sangat antusias mendengarkan pemaparan materi dari nara sumber, peserta sangat aktif melakukan tanyajawab. Selain penjelasan tentang makna Lamak dan Tamiang, dalam pertemuan itu nara sumber juga menjelaskan tentang bentuk dan jenis jenis Lamak yang dipergunakan dalam setiap upacara agama di Bali, sesuai dengan upacara atau jenis yadnya. Ada tiga jenis Lamak yang biasa dipergunakan dalam setiap upacara di Bali yaitu: Jenis Terujungan atau kalau di desa Guwang disebut cendiga, yang dipasang pada lebuh rumah, natah atau halaman rumah. Lamak kecil biasa di pasang pada pelinggih-pelinggih seperti : , pelangkiran, tugu-tugu. Lamak Besar dipasang pada pelinggih-pelinggih Utama seperti Gedong, Saren, Taksu dan Padmasana. Selain itu, Lamak biasanya dibuat dengan berbagai jenis ukuran, dari ukuran 2 meter sampai 6 meter, tergantung dari kebutuhan seberapa panjang dan penempatan dalam upacara yadnya. Kalau pendek, minimal di tiga bagian itu terdapat perwakilan dari Tri Loka tersebut. Misalnya di bawah cukup seperti reringgitan bebatuan atau tanah, di tengah bisa dalam bentuk reringgitan tumbuhan atau kekayonan, dan di atas ada matahari. Yang terpenting adalah menggambarkan alam atau isi dunia Karena konsepnya adalah Tri Bhuana tersebut, Panjang atau pendek sebuah Lamak harus memuat tiga unsur wajib yang dapat mewakili ketiga alam, yaitu bhur, bwah, swah. Selama ini ibu ibu hanya mengetahui nama Lamak tanpa tahu fungsi dan maknanya. Kalau dalam istilah Bali "nak mule keto uli pidan" (memang begitu dari dulu). Ada yang bisa membuat tetapi tidak mengetahui arti, makna dan fungsi sebenarnya Inilah yang ditekankan oleh nara sumber dalam pertemuan pelatihan ini. Pembelajaran dilanjutkan dengan pengenalan 
macam macam dan jenis reringgitan dalam sebuah Lamak. Reringgitan Lamak berupa motif hias : Ceracap, Bintang, Bulan, Gunung, Sarwa timuwuh, Cili, Bebatikan, Ceracap beten. Mas masan, gigin barong yang masing masing dapat mewakili symbol symbol alam.

Membuat reringgitan Lamak harus memiliki ketrampilan khusus dalam metetuesan. karena unik dan rumit. Lamak mengandung arti Simbolik dan Filosofis yang tinggi serta berpadu dengan Seni Rupa dan Seni hias yang mengagumkan sebagai ungkapan rasa syukur umatnya kepada Ida Sang Hyang Widhi Wase. Faktor Seni dalam jejahitan Lamak mempunyai arti penting karena dapat menuntun pikiran kearah keindahan menuju ketenangan Jiwa. Ketenangan untuk mencapai pemusatan pikiran dalam menuju Hyang Widhi, maka dari itu faktor Seni dalam agama Hindu di Bali saling terkait ,karena berperan sebagai unsur penunjang pelaksanaan Upacara Agama. Demikian juga dalam membuat tetuesan Tamiang, ketelatenan, dan keterampilan dalam metetuesan sangat mendukung bentuk Tamiang yang dihasilkan. Setelah diberi pemahaman tentang makna, fungsi dan bentuk bentuk tetuesan atau reringgitan Lamak dan Tamiang, dilanjutkan dengan praktek langsung metetuesan, diawali dengan bentuk reringgitan yang sederhana terlebih dahulu, kemudian dilanjutkan dengan membuat reringgitan yang lebih rumit. Para peserta pelatihan mengikuti pembelajaran dengan mempraktekan langsung menggunakan janur dan ron (daun enau yang tua). Pelatihan dan pendampingan dilanjutkan pada pertemuan berikutnya dengan praktek merangkai reringgitan sesuai dengan tatwa agama Hindu. Peserta pelatihan dibagi menjadi 4 kelompok masing-masing membuat reringgitan sesuai dengan penempatan pada bagian-bagian Lamak.Untuk menumbuhkan suasana keakraban antara naras sumber, team pelaksana dan peserta diberikan kebebasan untuk melakukan tanyajawab dalam kegiatan ini. Pada akhir pertemuan dilakukan evaluasi guna mengetahui untuk mengetahui sejauh mana kegiatan ini telah berjalan dan bermanfaat bagi mintra. Pelaksanaan pelatihan disesuaikan dengan situasi dan kondisi daerah dan kesibukan ibu ibu WHDI desa Guwang. Pelaksanaan pelatihan dijadwalkan di sore hari mulai pukul 15.00 sampai 17.00 Wita. Berikut beberapa gambaran suasana pelatihan membuat Lamak dan Tamiang;

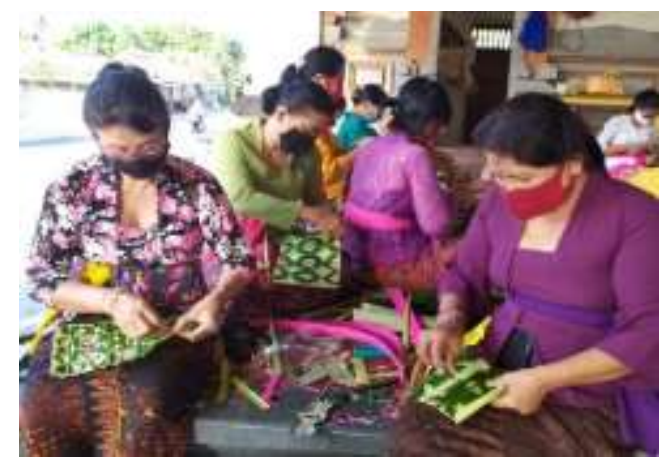

Gambar 1: Kegiatan membuat Lamak

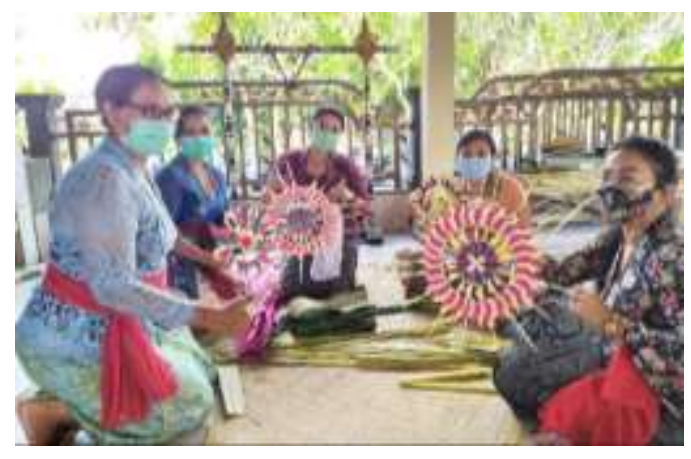

Gambar 2: Kegiatan membuat Tamiang

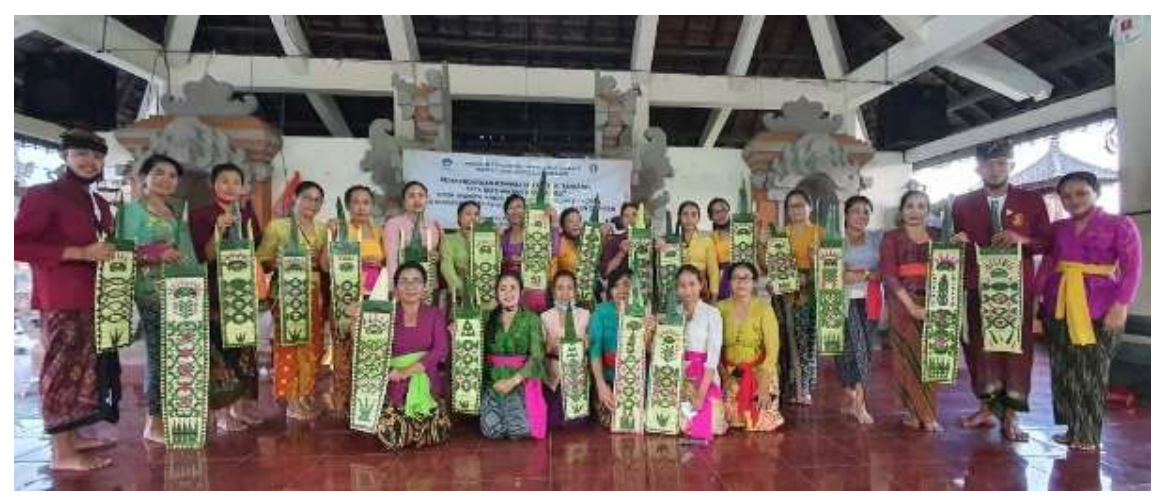

Gambar 3: Hasil karya lamak yang dikerjakan oleh ibu ibu WHDI desa Guwang dalam pelatihan 


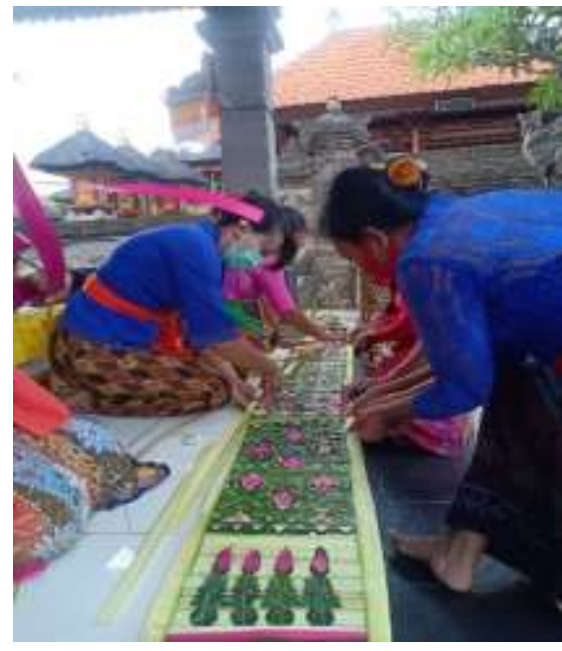

Gambar 4: Membuat lamak berukuran 5 meter

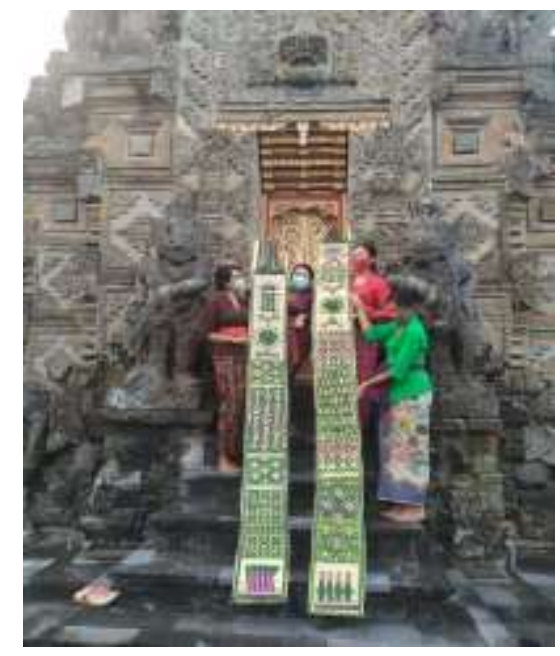

Gambar 5: Bentuk Lamak hasil dari pelatihan
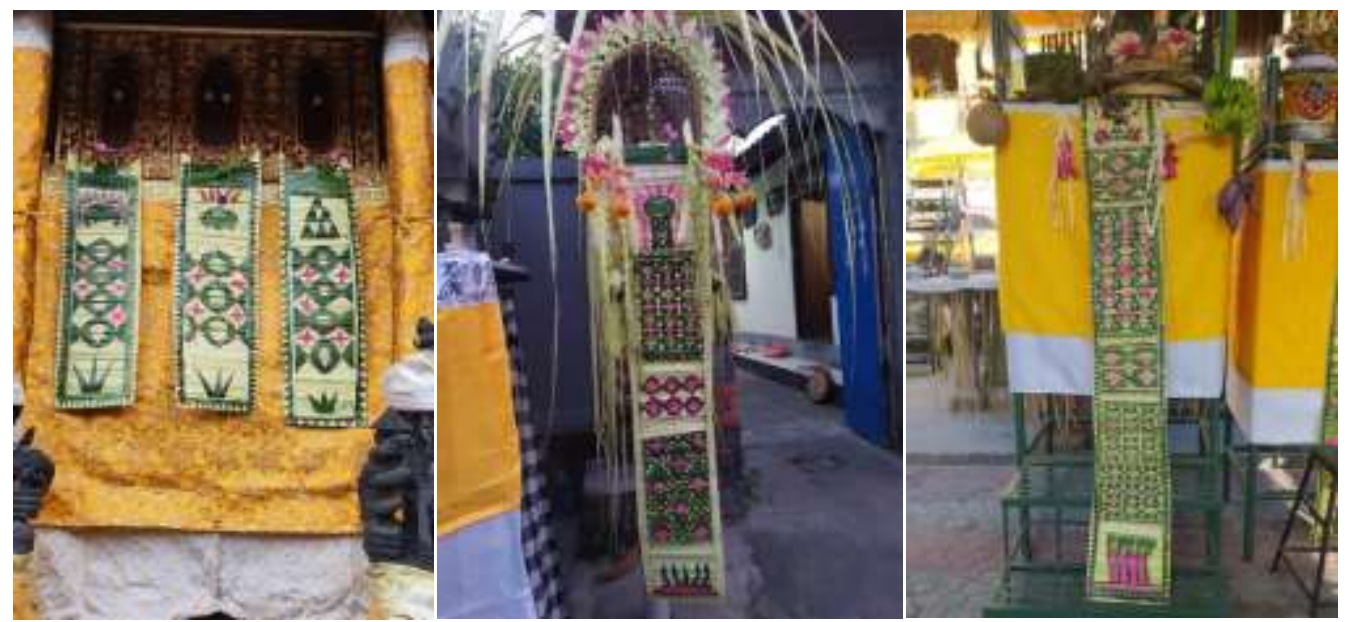

Gambar 6: Beberapa Bentuk Lamak hasil dari pelatihan yang langsung diterapkan pada bangunan suci

Setelah kelompok Wanita Hindu Dharma (WHDI) Desa Guwang mendapatkan pelatihan membuat Lamak dan Tamiang yang merupakan salah satu sarana upacara keagaamaan, pelatihan kembali berlanjut dengan pelatihan mengenai tata rias wajah dan rambut. Selain mempersembahkan sarana upacara yang indah, wujud rasa bakti dalam beryadnya juga ditampilkan melalui penampilan diri yang bersih, rapi dan indah. Tata rias wajah dan tata rambut memegang peran penting untuk mendukung tampilan berbusana yang elegan, rapi dan bersih. Untuk memberi tampilan wajah yang segar dan menambah kecantikan wajah maka perlu dilakukan penggunaan make up untuk tata rias wajah. Make up memiliki fungsi untuk membuat penampilan seorang wanita semakin menawan. Make-up secara psikologis memiliki dua fungsi yaitu fungsi seduction dan camouflage. Fungsi seduction artinya individu menggunakan make-up untuk meningkatkan penampilan diri. Fungsi camouflage artinya individu menggunakan makeup untuk menutupi kekurangan diri secara fisik (Korichi, Pelle-de-Queral, Gazano, dan Aubert (2008).

Dewasa ini, para wanita Hindu telah terbiasa dengan tampilan wajah dengan makeup dan tatanan rambut disanggul saat menghadiri atau mengikuti kegiatan keagamaan. Terlebih bagi para ibu-ibu yang tergabung dalam kelompok Wanita Hindu Dharma Indonesia (WHDI) yang aktif terlibat dalam kegiatan ngayah maka tata rias makeup dan rambut yang sesuai diperlukan untuk mendukung penampilan diri. Keberadaan kelompok Wanita Hindu Dharma Indonesia juga 
menjadi cerminan dan dijadikan contoh bagi wanita Hindu lainnya dalam berbusana dan menata diri untuk menghadiri acara keagamaan. Oleh karena itu diperlukan keterampilan dalam merias wajah maupun rambut secara mandiri sehingga akan memudahkan pada saat menghadiri kegiatan keagamaan maupun adat. Dalam pelatihan tata rias wajah dan rambut bagi kelompok WHDI Desa Guwang dipaparkan materi mengenai tata rias wajah, jenis make up, fungsi make up serta alat makeup dan cara penggunaannya. Pelatihan tata rias wajah yang diajarkan kepada kelompok WHDI Desa Guwang adalah tampilan make up minimalis yang telah disesuaikan untuk tata rias busana ke Pura. Pengenalan alat-alat make up seperti pelembab wajah (primer), alas bedak (foundation), bedak (powder), pensil alis, eye shadow, eyeliner, mascara, lipstick dan merah pipi (blush on) serta berbagai jenis kuas (brush) dan kegunaannya menjadi tahap awal dalam pelatihan tata rias wajah. Kemudian dilanjutkan dengan penjelasan mengenai produk makeup yang digunakan serta fungsinya untuk menghasilkan riasan wajah yang cantik dan sesuai untuk dipadankan dengan busana ke Pura. Para ibu- ibu peserta pelatihan terlihat antusias menyimak setiap pemaparan narasumber untuk segera dapat dipraktekan secara mandiri. Pada sesi pelatihan dalam mempraktekkan tata rias minimalis ini peserta dibagi dalam 4 kelompok untuk mempermudah demontrasi cara merias wajah yang diperagakan terlebih dahulu oleh narasumber, kemudian diikuti dengan baik oleh para peserta.

Narasumber memperagakan langkah-langkah dalam mengaplikasikan makeup pada wajah mulai dari penggunaan pelembab wajah, foundation, bedak, eyeshadow, eyeliner, pensil alis, pemasangan bulu mata palsu, perona pipi (blush on), hingga lipstik. Untuk menghasilkan tampilan makeup minimalis pemilihan warna eyeshadow dengan warna-warna lembut seperti, nuasana warna coklat, warna peach dengan sentuhan coklat tua disudut mata dapat memberi kesan fresh look dan natural. Tampilan makeup minimalis akan semakin didukung dengan penggunaan warna lisptik yang tidak terlalu mencolok seperti pilihan warna nude dan mauve. Peserta mengikuti dengan baik setiap langkah demi langkah tata cara penggunaan makeup yang diperagakan oleh narasumber, dalam sesi ini peserta juga dapat menanyakan narasumber jika ada hal-hal yang kurang dipahami.

Setelah para peserta berhasil mempraktekkan tata rias wajah, pelatihan selanjutnya mengenai tata rias rambut. Wanita Hindu saat menghadiri acara keagamaan atau berbusana adat ke Pura senatiasa menata rambut dengan cara di- sanggul agar terlihat rapi. Pelatihan diawali dengan pemaparan materi mengenai sanggul Bali, baik berupa tata cara menata rambut dengan sanggul hingga makna mesanggul tersebut bagi wanita Hindu. Dewasa ini masyarakat kurang mengetahui makna dari tata rias mesanggul ini, yang nantinya diharapkan dapat lebih menumbuhkan kecintaan para wanita Hindu untuk menata rambut dengan mesanggul khususnya wanita yang telah menikah pada setiap kesempatan saat mengikuti kegiatan keagamaan maupun adat. Setelah penyampaian materi oleh narasumber, dilanjutkan dengan demonstrasi tata cara mesanggul oleh narasumber yang diikuti oleh para peserta, dalam sesi ini peserta juga dipersilahkan untuk bertanya mengenai hal yang kurang dipahami saat mempraktekkan tata rias rambut mesanggul. Tata rias rambut mesanggul tidak menggunakan rambut asli dari peserta namun membutuhkan sebuah cemara yang telah dibentuk sedemikian rupa membentuk sanggulan, sehingga memudahkan peserta dalam melakukan tata rias rambut mesanggul. Alat yang diperlukan juga sangat sederhana yaitu sisir sasak, karet rambut, hair pin, dan hair spray. Para wanita yang menata rambut dengan sanggul, terlebih dulu harus menyasak rambut bagian depan dengan sisi sasak agar rambut menjadi kaku dan bervolume sehingga dapat dibentuk lengkungan setengah lingkaran. Hair spray digunakan untuk membuat rambut kaku dan rapi. Setelah rambut bagian depan dibentuk lengkungan setengah lingkaran, kemudia sisa rambut dibagian belakang dirapikan dengan diikat cepol yang selanjutnya dipasangkan sanggul sehingga sisa rambut bagian belakang tertutup oleh sanggul dengan rapi. Tampilan tata rambut mesanggul akan lebih cantik dengan penambahan bunga semanggi emas yang diletakkan di bagian atas sanggul atau menambahkan bunga mawar di samping kanan atau kiri bawah sanggul. Pada akhir pertemuan dilakukan evaluasi untuk mengetahui sejauh mana pelatihan ini dapat memberi maanfaat bagi para peserta. 
Pelaksanaan pelatihan tata rias ini juga disesuaikan waktunya dengan situasi dan kondisi daerah dan kesibukan ibu ibu WHDI desa Guwang. Berikut beberapa gambaran suasana pelatihan tata rias wajah dan rambut:
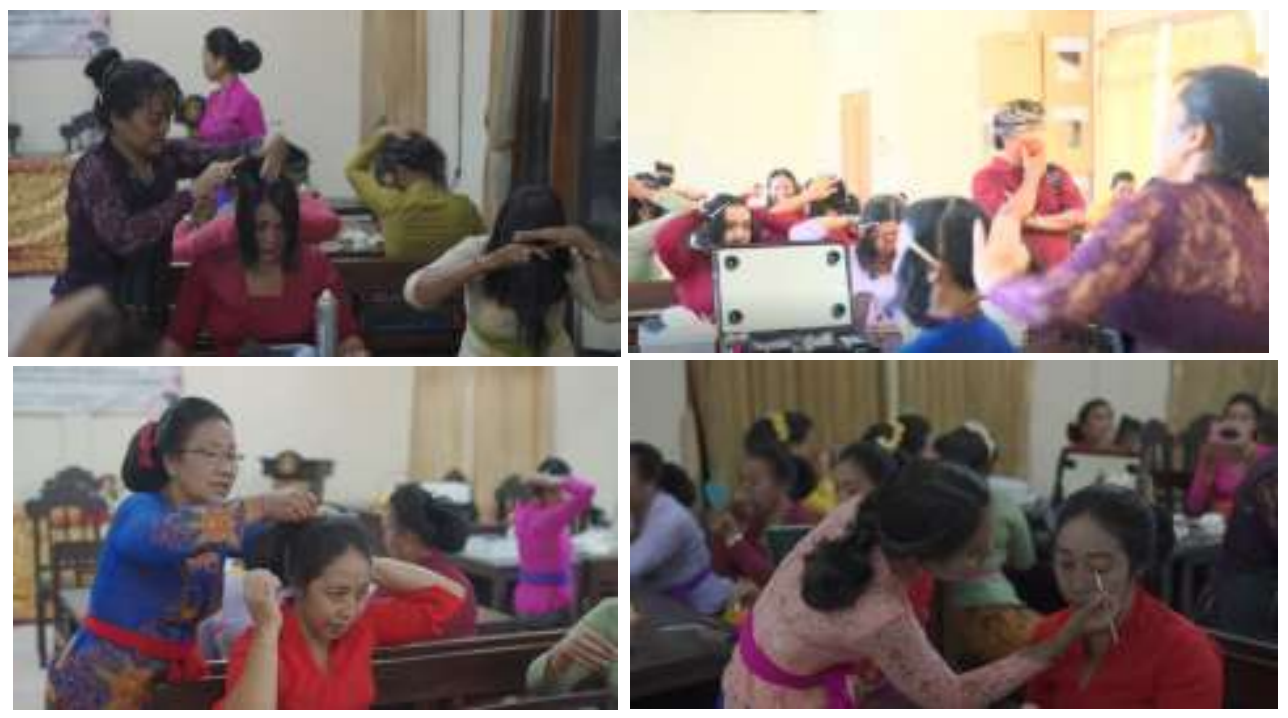

Gambar 7: Kegiatan pelatihan tata rias dan mesanggul Bali

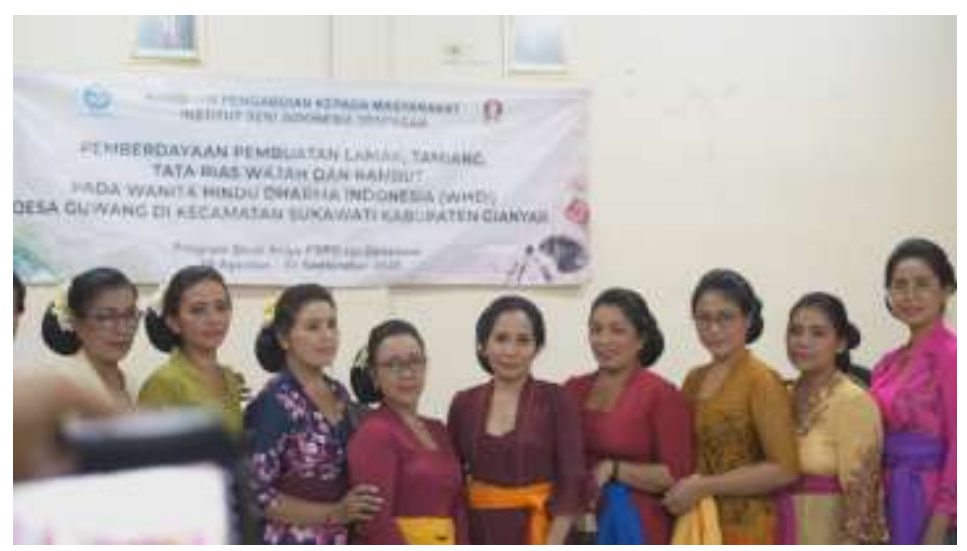

Gambar 8: Hasil dari pelatihan tata rias wajah dan rambut untuk ke Pura

\section{KESIMPULAN}

Kesimpulan yang dapat disampaikan setelah melakukan pengabdian masyarakat dengan mengadakan pelatihan membuat Lamak, Tamiang pada mitra yaitu kelompok WHDI desa Guwang adalah pembuatan Lamak dan Tamiang sudah terelialisasi, Mintra telah memahami akan makna, fungsi, bentuk Lamak dan Tamiang serta dapat membuat Lamak dan Tamiang yang baik dan benar sesuai dengan tatwa dalam agama Hindu di Bali.

Pelatihan mengenai tata rias wajah dan rambut juga telah terealisasi dengan baik yang diikuti dengan antusias oleh mitra. Mitra telah dapat mempraktekan langkah-langkah dalam menata rias wajah dan rambut dengan baik sesuai arahan narasumber. Mitra telah mampu melakukan rias wajah dengan makeup minimalis dan menata rambut mesanggul yang nantinya dapat diterapkan saat berbusana ke Pura, serta telah memahami esensi dari tatanan rambut mesanggul bagi wanita Hindu.

Secara umum program ini sudah terlaksana, namun masih perlu ditingkatkan agar diperoleh hasil yang lebih baik dan kaya akan macam dan jenis reringgitan Lamak dan Tamiang. 
Oleh karena itu kesungguhan dan keseriusan peserta yang menekuni bidang ini agar mampu membuat jenis-jenis dan bentuk bentuk Lamak yang lebih variatif dan indah. Sehingga Lamak dan Tamiang yang dibuat ini lebih menarik, diminati konsumen dan dapat menjadi tambahan ekonomi keluarga. Demikian juga dalam tata rias dan mesanggul, perlu dilakukan latihan secara berkesinambungan agar, menjadi terbiasa merias diri secara mandiri.

\section{UCAPAN TERIMA KASIH}

Kami Team pelaksana kegiatan pengabdian masyarakat dari Program Studi Kriya Fakultas Seni Rupa Dan Desain ISI Denpasar mengucapkan terimakasih kepada kelompok WHDI desa Guwang selaku mitra di desa Guwang kecamatan Sukawati kabupaten Gianyar. Ucapan terimakasih juga kami sampaikan kepada LP2MPP ISI Denpasar atas pendanaan yang telah diturunkan untuk kelancaran kegiatan pengabdian ini. Serta semua pihak yang telah membantu terwujudnya program pengabdian masyarakat ini.

\section{DAFTAR PUSTAKA}

Munawarah, Keumala Hayati, Mas Intan Purba, Wenny Anggeresia Ginting. (2020). Pemberdayaan Masyarakat Kelurahan Suka Maju Melalui Pelatihan Pembuatan Sabun Kebutuhan Rumah Tangga. DINAMISIA: Jurnal Pengabdian Kepada Masyarakat Vol. 4 No. 3 hal 434-439 https://doi.org/10.31849/dinamisia.v4i3.3910

Merta, Dewa, Ni Kadek Karuni. (2003). Ragam Hias Pada Jejahitan Lamak. Jurnal Penelitian Seni. Sekolah Tinggi Indonesia Denpasar.

Covarrubias, Miguel. (1973). Island of Bali. Asia Pasific.Berkeley Books Pte.Ltd.

Raka Ida Bagus, (1977/1978), Jejahitan Bali Serta Fungsinya, Proyek Sasana Budaya Bali.

Balitoursclub. (2020). Hari Raya Kuningan. Bali Tours Club

https://www.balitoursclub.net/hari-raya-kuningan/ 27 juni 2020

Doktrinaya,I Komang Gede (ed). (2020). Lamak Wajib Ada Aplikasi Tiga Alam.Jawa Pos Grup Bali Express.

https://baliexpress.jawapos.com/read/2020/06/18/199733/lamak-wajib-ada-aplikasi-tigaalam diakses 26 Juni 2020

Suyatra, I Putu (ed). 2017. Begini Makna Lamak Dalam Pelaksanaan Upacara di Bali. https://baliexpress.jawapos.com/read/2017/09/29/16298/begini-makna-Lamak-dalampelaksanaan-upacara-di-bali diakses tanggl 26 juni2020

KOWANI.2017. Wanita Hindu Dharma Indonesia. KOWANI Kongres Wanita Indonesia. https://kowani.or.id/wanita-hindu-dharma-indonesia/ diakses 27 Juni 2020

Yuwanto, Listyo. (2010). Fungsi Make- Up Dari Tinjauan Psikologi. Ubaya Universitas Surabaya https://www.ubaya.ac.id/2018/content/articles_detail/12/Fungsi-Make--up-dari-TinjauanPsikologi.html diakses 26 Juni 2020

(2011). Cili. Sejarah Hari Raya \& Upacara Yadnya di Bali. https://sejarahharirayahindu.blogspot.com/2011/12/cili.html diakses 28 Juli 2020. 